\title{
RELATIONSHIP BETWEEN GENDER AND LEARNING STYLE PREFERENCES- A STUDY AMONG UNDERGRADUATE MEDICAL STUDENTS IN SOUTH INDIA
}

\author{
Satya Raj ${ }^{1}$, Shankar Kanagasabapathy²
}

${ }_{1}^{1}$ Associate Professor, Department of Psychiatry, Unit of Child and Adolescent Psychiatry, Christian Medical College, Vellore, Tamilnadu, India.

2Professor, Department of Community Medicine, Meenakshi Medical College and Research Institute, Kancheepuram, Tamilnadu, India. ABSTRACT

\section{BACKGROUND}

Learning style is defined as the manner and condition under which learners most efficiently and effectively perceive, process, store and recall what they attempt to learn. Each student or learner has a dominant learning style. There are theories that speak about the innate differences between male and female in learning. This gender-based differences could affect their learning styles as well. One of the important criteria for academic achievement is to consider the students' differences and to identify their learning style and provide learning programs based on their needs. We wanted to determine the relationship between gender and learning style preferences among undergraduate medical students.

\section{METHODS}

This cross-sectional study was conducted among all the 150 students belonging to the first year of MBBS course in a medical college. There were 64 male students and 86 female students in the study population. The C.I.T.E. (Center for Innovative Teaching Experiences) learning styles instrument was used to assess the learning style. This instrument determines the learning styles under three broad areas, like, information gathering, work conditions and expressiveness.

\section{RESULTS}

In this study, all the students preferred more than one learning style as a major learning style. This study also observed a statistically significant $(\mathrm{p}<0.05)$ difference in the learning style preferences of male and female students.

\section{CONCLUSIONS}

It is imperative that the teacher is aware of the student's learning style, and gender differences, so as to develop appropriate teaching-learning methods to address this difference. Institutions of higher education should take gender difference in learning styles into their consideration while developing curriculum.

HOW TO CITE THIS ARTICLE: Raj S, Kanagasabapathy S. Relationship between gender and learning style preferences- a study among undergraduate medical students in South India. J. Evolution Med. Dent. Sci. 2019;8(19):1550-1554, DOI: $10.14260 /$ jemds/2019/344

\section{BACKGROUND}

Learning style is defined as the manner and condition under which learners most efficiently and effectively perceive, process, store and recall what they attempt to learn.(1) There are more than 21 models for learning Styles.(2) Each student or learner has a dominant learning style, based on his or her own goals, needs etc, . Learning style is also the best way by which an individual collects, organizes and learns new information. (3)

Teaching and learning improvement form the base of all activities in an educational institution. (4) If a student needs to achieve academic success, his or her learning styles have to be in alignment with the teaching styles of the instructor/teacher. To be a successful teacher, the faculty members in educational institutions should have an understanding of the student's learning style, apart from mastery in his or her subject domain and pedagogy skills.

'Financial or Other Competing Interest': None.

Submission 30-03-2019, Peer Review 28-04-2019,

Acceptance 02-05-2019, Published 13-05-2019.

Corresponding Author:

Dr. Shankar Kanagasabapathy,

Department of Community Medicine,

Meenakshi Medical College and Research Institute,

Enathur, Kancheepuram-631552, Tamilnadu, India.

E-mail: shankarsalem@yahoo.com

DOI: $10.14260 /$ jemds $/ 2019 / 344$

School teachers are more oriented to teaching - learning methods, when compared to faculty members in higher educational institutions like a Medical College, since they usually undergo significant long-term training in Teaching methodologies. The Medical council of India is trying to build the gap by making it mandatory for certain number of faculty in each medical college to be trained in Medical Education Technology.

One of the important criteria for academic achievement is to consider the students' differences and to identify their learning style, and provide learning programs based on their needs.(5) Educational research on learning styles is mainly focused on matching student learning styles with curriculum and various teaching styles.(6) One important reason for student's frustration is a mismatch between the teaching methods of the teacher, and the learning styles of the student.(7) If teaching methods are chosen based on the learning styles of the students, the outcomes are better. ${ }^{(8)}$

There are lots of factors that affect or interfere with the learning process in an academic environment. Physical factors like, visual or hearing impairment, psychological factors like attitude, motivation, and environmental factors like classroom atmosphere and even the personality of the teacher influence the student's learning.(9)

Similarly, gender is one such factor that affects the student's learning style. There are theories that speak about the innate differences between male and female in learning.(10) This gender-based differences could affect their 
learning styles as well. Studies have shown that traditional educational curriculum in India does not support all the preferred learning styles.(11)

In many medical schools, across the globe, the assessment of student learning styles is done periodically to increase awareness among the teachers.(12) This concept is yet to catch-up in India. This study was done on a fresh batch of students in a Medical college to ascertain the relationship between gender and their learning style preferences.

\section{METHODS}

There are many methods to assess the learning styles of students. Each and every one of these methods offers a distinctly different view of the learning style preferences. This study used the C.I.T.E. (Center for Innovative Teaching Experiences) Learning style instrument,(13) developed by the Murdoch Teachers Center in Wichita, Kansas for assessing the learning style preferences among students. The instrument consists of 44 statements, and the responses marked on a four-point Likert scale. It is divided into three main areas, Information gathering, Work condition and Expressiveness.

\section{Information Gathering}

This area includes auditory language, visual language, auditory numerical, visual numerical, and a combination of auditory-visual and kinaesthetic.

\section{Work Condition}

The focus is on whether a student works better alone or in a group.

\section{Expressiveness}

This demonstrates whether a student is better at oral or written communication. These are the different learning styles assessed by the C.I.T.E. Instrument-

\section{Visual-Language}

The student, who prefers this type of learning style, learns well by seeing words on charts, books, blackboard, etc. They remember information better by reading.

\section{Visual-Numerical}

This student prefers numbers on the board or book, to read. He or she has to see numbers to remember it.

\section{Auditory-Language}

These students would like to learn by hearing words spoken. One can see them vocalizing while reading. They tend to perform well, if they learn by hearing.

\section{Auditory-Numerical}

The students here, learn from hearing numbers and oral explanations, and they are successful with oral numbers, puzzles, etc. They can solve problems in their head.

\section{Auditory-Visual-Kinaesthetic}

Here, the student learns by experience and self-involvement. These students seek to touch and work with what is being learned. They prefer to manipulate the material, along with hearing the related sounds and looking at things.

\section{Social-Individual}

The student, who prefers this mode of learning, would like to work alone. They care more about their own opinions than that of others.

\section{Social-Group}

This student values the ideas and preferences of other students. The student gives importance to socializing. He or She tends tom learn better by socializing.

\section{Expressive-Oral}

The student talks clearly and fluently. The student is less shy than others in oral presentations. Since organizing and putting thoughts on paper is tough for the student, the written test may not reflect the true capability of the student.

\section{Expressiveness-Written}

This student has his or her thoughts better organized in a theory paper, than while answering oral examinations. These students feel less comfortable while answering oral questions compared to written answers. Scores in the learning style inventory fall into any one of the three categories, Major, Minor and Negligible.

\section{Major}

The student feels comfortable with this mode of learning and prefers this for important learning.

\section{Minor}

This learning mode is used by the student as a second choice, or in conjunction with other learning styles.

\section{Negligible}

The student does not prefer to use this learning style if other choices are available. It's important to note that a student can have more than one preferred learning style. This crosssectional study was done in a Medical College in Kanchipuram district of Tamil Nadu. The medical college has an annual intake of 150 students, and all the 150 students belonging to the first year of the MBBS course were included in the sampling frame. After obtaining informed consent, and assuring them of complete confidentiality, all the students were administered the C.I.T.E. instrument. The absentees on the day of assessment were followed up on subsequent days, so that all the 150 were enrolled in the study.

\section{Statistical Analysis}

The data was tabulated, and analysed using SPSS (Statistical package for Social Sciences) version -18. A Pearson chisquare test was done to determine whether there was a significant association between gender and their learning style preferences.

\section{RESULTS}

A total of 150 students belonging to the class of first MBBS took part in the study. There were 64 male students and 86 female students in the study sample. The data for the overall group show that in the area of information gathering, the Auditory-visual-kinaesthetic learning style was the most common major learning style, with was favoured by around $65 \%$ of the students, and the Auditory language learning style was the least common Major learning style, with only $30 \%$ of 
the students following the same. In the same information gathering category, $63 \%$ students, had Auditory-language as the Minor learning style, and only $34 \%$ students had Auditory-visual-kinaesthetic as a Minor learning style. None of the students had negligible use of any of the learning styles, except $12 \%$ and $6 \%$ of them, in visual-numerical and auditory-language category, respectively.
In the domain of work condition, $71.3 \%$ of students had social-Individual as the major learning style, and only $46.7 \%$ had social-group as a Major learning style. Similarly, in the area of expressiveness, the learning styles of expressive-oral and expressive-written, for many students, were Minor only, and also, 5.3\% of students had expressive-oral as a negligible learning style. Details are given in table -I.

\begin{tabular}{|c|c|c|c|}
\hline \multirow{2}{*}{ Learning Style } & Major & Minor & Negligible \\
\cline { 2 - 4 } & \multicolumn{2}{|c|}{ Information Gathering } & - \\
\hline Visual - Language & $74(49.3 \%)$ & $76(50.7 \%)$ & $18(12 \%)$ \\
\hline Visual - Numerical & $63(42 \%)$ & $99(46 \%)$ & $9(6 \%)$ \\
\hline Auditory - Language & $46(30.7 \%)$ & $89(63.3 \%)$ & - \\
\hline Auditory - Numerical & $61(40.7 \%)$ & $52(34.7)$ & - \\
\hline Auditory-Visual-Kinaesthetic & $98(65.3 \%)$ & $43(21.7 \%)$ & $9(6 \%)$ \\
\hline \multicolumn{7}{|c|}{ Work Conditions } \\
\hline Social-Individual & $107(71.3 \%)$ & $71(47.3 \%)$ & $8(5.3 \%)$ \\
\hline Social-Group & $70(46.7 \%)$ & \\
\hline
\end{tabular}

\begin{tabular}{|c|c|c|c|c|c|c|}
\hline \multirow{2}{*}{ Learning Style } & \multirow{2}{*}{ Sex } & \multicolumn{3}{|c|}{ Learning Style Category } & \multirow{2}{*}{ Chi-square } & \multirow{2}{*}{ p-Value } \\
\hline & & Major & Minor & Negligible & & \\
\hline \multicolumn{7}{|c|}{ Information Gathering } \\
\hline \multirow{2}{*}{ Visual - Language } & Male & $40(62.5 \%)$ & $24(37.5 \%)$ & 0 & \multirow{2}{*}{7.742} & \multirow{2}{*}{0.005} \\
\hline & Female & $34(39.5 \%)$ & $52(60.5 \%)$ & 0 & & \\
\hline \multirow{2}{*}{ Visual - Numerical } & Male & $16(25 \%)$ & $40(62.5 \%)$ & $8(12.5 \%)$ & \multirow{2}{*}{6.879} & \multirow{2}{*}{0.032} \\
\hline & Female & $39(45.3 \%)$ & $37(43 \%)$ & $10(11.7 \%)$ & & \\
\hline \multirow{2}{*}{ Auditory - Language } & Male & $18(28.1 \%)$ & $46(71.9 \%)$ & 0 & \multirow{2}{*}{8.219} & \multirow{2}{*}{0.016} \\
\hline & Female & $28(32.5 \%)$ & $49(57 \%)$ & $9(10.5 \%)$ & & \\
\hline \multirow{2}{*}{ Auditory - Numerical } & Male & $16(25 \%)$ & $48(75 \%)$ & 0 & \multirow{2}{*}{11.355} & \multirow{2}{*}{0.001} \\
\hline & Female & $45(52.3 \%)$ & $41(47.7 \%)$ & 0 & & \\
\hline \multirow{2}{*}{$\begin{array}{l}\text { Auditory-Visual- } \\
\text { Kinaesthetic }\end{array}$} & Male & $32(50 \%)$ & $32(50 \%)$ & 0 & \multirow{2}{*}{11.588} & \multirow{2}{*}{0.001} \\
\hline & Female & $66(76.7 \%)$ & $20(23.3 \%)$ & 0 & & \\
\hline \multicolumn{7}{|c|}{ Work Conditions } \\
\hline \multirow{2}{*}{ Social-Individual } & Male & $42(65.6 \%)$ & $22(34.4 \%)$ & 0 & \multirow{2}{*}{1.779} & \multirow{2}{*}{0.182} \\
\hline & Female & $65(75.6 \%)$ & $21(24.4 \%)$ & 0 & & \\
\hline \multirow{2}{*}{ Social-Group } & Male & $32(50 \%)$ & $32(50 \%)$ & 0 & \multirow{2}{*}{7.131} & \multirow{2}{*}{0.028} \\
\hline & Female & $38(44.2 \%)$ & $39(45.3 \%)$ & $9(10.5 \%)$ & & \\
\hline \multicolumn{7}{|c|}{ Expressiveness } \\
\hline \multirow{2}{*}{ Expressive -Oral } & Male & $30(46.9 \%)$ & $34(53.1 \%)$ & 0 & \multirow{2}{*}{7.027} & \multirow{2}{*}{0.030} \\
\hline & Female & $31(36 \%)$ & $47(54.7 \%)$ & $8(9.3 \%)$ & & \\
\hline \multirow{2}{*}{ Expressive-written } & Male & $18(28.1 \%)$ & $46(71.9 \%)$ & 0 & \multirow{2}{*}{4.046} & \\
\hline & Female & $38(44.2 \%)$ & $48(55.8 \%)$ & 0 & & 0.044 \\
\hline & Table II. & Differences it & Learning Sty & ong the St & & \\
\hline
\end{tabular}

In each of the learning style category, sex difference was analysed. It was observed that $62.5 \%$ of male students had Visual-language as a major learning style, in contrast to $39.5 \%$ of the female students. Similar was the case with Visual-Numerical, wherein, more female students (45.3\%) had this as a major learning style, compared to male students. Moreover, $12.5 \%$ of female students and $11.7 \%$ of male students had negligible use of this learning style. In the Auditory-Language learning style category, $71.9 \%$ of male students and $57 \%$ of female students had it as a minor learning style only, and $10.5 \%$ of females considered it to be negligible learning style, whereas, none of the male students opined that it is negligible. Likewise, $76.7 \%$ of the female students had, auditory-Visual-kinaesthetic as a Major learning style, compared to only $50 \%$ of the males. In the area of information gathering, there was a statistically significant difference between male and female students in all the five learning styles. Details provided in table- II.

The sex difference in learning styles under the category of work conditions, also paints more or less a similar picture. The social-individual learning style was the major learning style among $65.6 \%$ male students and $75.6 \%$ female students. Whereas, the social-group learning style was the major learning style in $50 \%$ of the male students and $44.2 \%$ of the female students, and for around $10.5 \%$ of the female students, social-group was a negligible learning style. This difference among the sexes in the Social - group learning style was found to be statistically significant.

In the domain of expressiveness, $46.9 \%$ of male students and $36 \%$ of female students had expressive - oral as their 
major learning style and among the later, 9.3\% had expressive-oral as a negligible learning style. Similarly, $28.1 \%$ of male students and $44.2 \%$ of female students had expressive-written as a major learning style. This difference between the two sexes was found to be statistically significant. Details are given in table -II.

\section{DISCUSSION}

Though the primary objective of this study was to assess the gender difference in learning styles among undergraduate medical students, the overall picture of the prevalent learning styles among the study population showed that all the students preferred more than one leaning style as a Major one. In a similar study done at the University of Michigan,(14) it was observed that most students preferred multiple learning styles. Studies have shown that, for effective learning to occur, students need to apply multiple learning styles in different learning situations. Especially, students of medicine should be advised to apply multiple learning styles in their learning period.(15) This study was conducted only among the first year MBBS students in one chosen medical college, where, both the genders are exposed to similar subject matters, teachers and teaching methodologies. But, the majority of them come from different demographic backgrounds. Nasirzadeh(16) opined that demographic characteristics can affect the learning styles of students. It's also true that learning styles are not fixed, and can change over time, due to the influence of the teaching methods, subject and leaning environment.(17)

This study observed a significant difference between the male and the female students in their learning style preferences in all the three areas assessed, ie.. Information gathering, work conditions and expressiveness. The only learning style which had no significant difference between the sexes was Social-Group, where more or less the similar percentage of male and female students preferred the socialindividual as a major learning style. Couple of studies conducted by Sarabi et.al,(18) and Mohammadi et. al,(19) observed a significant relationship between gender and learning styles. Another study done by Honigsfeld et.al,(20) in 5 different countries also observed a relationship between gender and learning styles. A study done by Amni and others, (21) found some difference between gender and learning styles, but the difference was not statistically significant. On the contrary, there were also some studies(22) that did not find any difference between the genders in their preferred learning styles.

Some literature is available on this topic of Gender difference in learning. Studies have shown that male students have a preference for rational evaluation and logic, whereas, women try to look for a individual connection, or personal relevance with the material that is thought.(23) Male students tend to be more achievement oriented, whereas, female students are more socially and performance oriented.(24)

\section{CONCLUSIONS}

This study done among medical students, observed a significant association between gender and their learning style preferences. So, it becomes imperative that the teacher is aware of the student's learning style, and gender differences, so as to develop appropriate teaching methodologies to address this difference. Institutions of higher education should take gender difference in learning styles into consideration while developing curriculum. As mentioned by Lie et al, (23) this gender difference in learning style preferences support mixed gender classrooms and study groups in institutions, so that both the genders can complement each other in the learning process.

\section{REFERENCES}

[1] James WB, Gardner DL. Learning styles: implication of distance learning. New Dir Adult Conti Educ 1995;67:19-31.

[2] Curry L. An organization of learning style theory and constructs. Paper presented at the Annual Meeting of the American Educational Research Association '83. Montreal, Quebec: Educational Resources Information Center (ERIC) 1983.

[3] Ismail WCN, Azman N. Diverse learning styles of nonformal adult learners in community colleges in Malaysia. Procedia-Social and Behavioral Sciences 2010;7:139-44.

[4] Kalbasi S, Naseri M, Sharifzadeh G, et al. Medical students' learning styles in Birjand University of Medical Sciences. Strides in Development of Medical Education. Strides in Development of Medical Education 2008;5(1):10-6.

[5] Scott E, Rodríguez G, Soria Á, et al. Are learning styles useful indicators to discover how students use Scrum for the first time? Computers in Human Behavior 2014;36:56-64.

[6] Mainemelis C, Boyatzis RE, Kolb DA. Experiential learning theory: Previous research and new directions. In: Sternberg RJ, Zhang L, eds. Perspectives on thinking, learning and cognitive styles. Mahwah, N.J.: Lawrence Erlbaum Associates 2001:227-48.

[7] Bertolami CN. Rationalizing the dental curriculum in light of current disease prevalence and patient demand for treatment: form vs. content. J Dent Educ 2001;65(8):725-35.

[8] Kolb AY, Kolb DA. Learning styles and learning spaces: Enhancing experiential learning in higher education. Academy of Management Learning \& Education 2005;4(2):193-212.

[9] Abante MER, Almendral BC, Manansala JE, et al. Learning styles and factors affecting the learning of general engineering students. International Journal of Academic Research in Progressive Education and Development. 2014;3(1):16-27.

[10] Glazer S. Gender and learning: are there innate differences between the sexes? CQ Res 2005;15:44568.

[11] Philbin M, Meier E, Huffman S, et al. A survey of gender and learning styles. Sex Roles 1995;32(7-8):485-94.

[12] Shakurnia A, Ghafourian M, Alhampor H. Comparing approaches to study and learn of the basic and clinical medical students and its relationship to academic achievement. Strides Dev Med Educ 2012;9(2):132-42.

[13] Babich AM, Burdine P, Albright L, et al. C.I.T.E. Learning Styles Instrument. Center for Innovative Teaching Experiences. Wichita, KS: Murdoch Teachers Center. 
https://www.iidc.indiana.edu/styles/iidc/defiles/INS TRC/TuesTips/learning_style_inventory.pdf

[14] Urval RP, Kamath A, Ullal S, et al. Assessment of learning styles of undergraduate medical students using the VARK questionnaire and the influence of sex and academic performance. Advances in physiology education. Adv Physiol Educ 2014;38(3):216-20.

[15] Ahadi F, Abedsaidi J, Arshadi F, et al. Learning styles of nursing and allied health students in Semnan university of medical sciences. Koomesh J Semnan University of Medical Sciences 2010;11(2):141-6.

[16] Nasirzadeh F, Heidarzadeh A, Shirazi M, et al. Assessing learning styles of students in Guilan University of Medical Sciences, 2013. Research in Medical Education 2014;6(1):29-39.

[17] Curry L. Cognitive and learning styles in medical education. Acad Med 1999;74(4):409-13.

[18] Sarabi-Asiabar A, Jafari M, Sadeghifar J, et al. The relationship between learning style preferences and gender, educational major and status in first year medical students: a survey study from Iran. Iran Red Crescent Med J 2015;17(1):e18250.
[19] Mohammadi S, Mobarhan MG, Mohammadi M, et al. Age and gender as determinants of learning style among medical students. British Journal of Medicine and Medical Research 2015;7(4):292-8.

[20] Honigsfeld A, Dunn R. High school male and female learning-style similarities and differences in diverse nations. The Journal of Educational Research 2003;96(4):195-206.

[21] Amini N, Zamani BE, Abedini Y. Medical students' learning styles. Iranian Journal of Medical Education 2010;10(2):141-7.

[22] Alkhasawneh IM, Mrayyan MT, Docherty C, et al. Problem-based learning (PBL): assessing students' learning preferences using VARK. Nurse Educ Today 2008;28(5):572-9.

[23] Lie LY, Angelique L, Cheong E. How do male and female students approach learning at NUS? CDTL Brief 2004;7(1):1-3.

[24] Chang WC. Learning goals and styles by gender a study of NUS students. CDTL Brief 2004;7(1):4-5. 